\title{
COMUNIDADE KALUNGA: TRABALHO E CULTURA EM TERRA DE NEGRO
}

\author{
GILMAR ALVES DE AVELAR \\ Universidade Federal de Goiás - Campus de Catalão \\ MARISE VICENTE DE PAULA ${ }^{* *}$
}

\section{Apresentação}

O presente artigo foi construído a partir de experiências vivenciadas em viagem a campo junto às Comunidades Kalunga nos povoados de Vão de Alma, Vão do Moleque, Engenho e Diadema. Esses povoados estão localizados próximos aos municípios de Teresina de Goiás/ GO e Cavalcante/ GO e a viagem ocorreu nos dias 11 a 26 de agosto de 1999, realizada através do Projeto Quilombos, em parceria com a UFG, UnB, Universidade Solidária e Fundação Palmares.

O principal objetivo dos grupos envolvidos foi reconhecer os hábitos quotidianos, costumes e estórias das Comunidades Kalunga. Para tanto, foi desenvolvida uma série de trabalhos de pesquisa (entrevistas, questionários e rodas de conversação informal) e extensão (seminários de orientação para crianças e adultos sobre temas variados construídos sob fundamentos teóricos multidisciplinares).

Como resultado da pesquisa realizada em campo no Projeto Quilombos, desenvolvemos, em parceria com a Câmara Municipal de Catalão, Fundação Cultural

\footnotetext{
Doutorando do Programa de Pós-Graduação em Geografia da Universidade Federal Fluminense. Professor Assistente do Curso de Geografia da Universidade Federal de Goiás -Campus de Catalão

Mestre em Geografia pelo Programa de Pós-Graduação em Geografia da Universidade Federal de Goiás
} 
Maria das Dores Campos e Campus de Catalão/UFG, um projeto de extensão junto às escolas da rede pública da cidade de Catalão/GO, de abril a agosto de 2000 , em forma de ciclos de debate, com a temática Comunidade Kalunga: Trabalho e Cultura em Terra de Negro, que visava lançar uma discussão acerca de tal agrupamento, debater a questão do negro no Brasil na atualidade, bem como promover uma interação entre a Escola e a Universidade, diversificando e enriquecendo o campo do conhecimento.

Assim, neste artigo, intencionávamos tratar, além das impressões gerais obtidas em relação à cultura, costumes e história deste povo, de enfocar a caracterização do agrupamento Kalunga, segundo as quatro áreas pesquisadas, em relação ao uso e posse da terra, suscitando assim reflexões acerca de categorias de análise como território negro, quilombo e isolamento.

\section{O negro em Goiás}

No contexto nacional que envolve o desenvolvimento econômico do Estado de Goiás, o negro aparece com expressão, primeiramente, segundo historiadores e antropólogos que abordaram esta parte do território brasileiro, por volta do século XVII, junto às bandeiras colonizadoras, seguindo o movimento minerador do ciclo do ouro e, mais tarde, o movimento migratório dos mineiros e baianos, em busca de terras para plantio e pastagens.

Considera-se, assim, que a presença negra em Goiás tem um importante papel na formação étnica e evolução sócio-econômica do Estado:

O negro foi o elemento principal que possibilitou a colonização do vasto território goiano, com seu trabalho nas minas, abarrotava os cofres da coroa, permitia abastança dos senhores e deitava na terra as sementes da subsistência do homem, implantando a lavoura de subsistência, que mais tarde florescia. (BAIOCCHI, 1983: 19).

Mesmo diante da relevância do trabalho escravo em Goiás, considerando sua importante participação no desenvolvimento econômico do Estado, os maus tratos e a violência contra os negros sempre foram comuns, assim como foi no movimento escravista em todo território nacional. O negro era visto como um ser não europeu, não cristão, como assim o eram os índios, não possuía alma nem atributos de humanidade, podendo ser tratados como animais, numa qualidade de simples mercadoria.

Várias foram as formas de resistência negra diante deste quadro lamentável, entre as quais citamos o aborto e o suicídio. As fugas também representaram grandes movimentos de resistência à escravidão, dando origem a quilombos, organizações que assinalaram a história colonial brasileira. Em vários casos, como na Comunidade Kalunga, resistiram até os dias atuais (MATTOSO, 1982).

A década de 1870 é uma das possíveis datas de início da formação dos primeiros quilombos em Goiás, devido às fugas de escravos indígenas que já ocorriam no séc. 
XVII, bem como as evidências que indicam a incidência de escravos fugidos do Maranhão, Bahia e Pernambuco, que percorriam a rota do sertão em destino ao norte e nordeste de Goiás. Documentos e tradições orais sobre os quilombos em Goiás, analisados por Karash (1996), no entanto, datam-nos, em grande parte, do século XVIII. Goiás se torna, neste contexto, território de refúgio e resistência conforme esclarece o historiador Palacín:

Se a existência de quilombos implica maus tratos para o escravo, em Goiás constitui um testemunho impressionante, pois não há, praticamente, arraial sem a sombra de seu quilombo. (PALACIN, 1972: 93).

O sertão goiano era visto pela colônia como sinônimo de terras a desbravar e que, por isso, estavam sendo descobertas. Para Almeida:

O sertão trazia consigo marcas do processo colonizador, refletindo a linguagem do outro, do civilizado. Era uma forma de nomear o desconhecido, expressando o pensamento do europeu sobre o novo continente. $O$ sertão passou a ter uma representação cultural e ideológica que reforçava o distanciamento entre o eu e o outro. (...) ele significava o incerto, o atrasado, o desconhecido, o longínquo, o selvagem" (ALMEIDA, 1996:37).

Desta forma, a capitania de Goiás oferecia condições ideais para o estabelecimento de quilombos, devido primeiramente a localização geográfica que guardava grande distância dos centros administrativos portugueses do litoral, estando assim afastada das forças militares coloniais responsáveis pela destruição de quilombos. Os oficiais enviados para Vila Boa, capital da capitania de Goiás, eram em número reduzido em relação à extensão de terras a guardar. Assim, os escravos fugidos de Goiás não tiveram que enfrentar exércitos bem treinados e numerosos como os dos quilombos do litoral, (KARASCH, 1996).

Os quilombolas viviam da roça, caça e pesca. Alguns grupos realizavam assaltos, porém, havia os que cuidavam de gado e produziam carne seca. Eles negociavam com os vizinhos ouro e alimentos, guerreavam com os índios e estabeleciam vários tipos de relações com as populações livres da fronteira, além de terem contribuído significativamente para a descoberta e exploração de riqueza mineral da capitania de Goiás, (KARASCH, 1996).

Foram detectados inúmeros quilombos em Goiás. Segundo Luiz Palacin, somente durante o governo de D. Marcos de Noronha há, através de suas correspondências, notícias de medidas tomadas contra quilombos em Arraias, Pirenópolis, Crixás, Paracatu e Três Barras, todos a caminho do norte de Minas Gerais, (PALACIN, 1972).

Segundo Silva:

Vários quilombos nunca foram descobertos pelos seus perseguidores e, depois da abolição da escravatura, muitos desses negros continuaram a morar no mesmo local, formando-se assim os atuais bairros rurais de negros e remanescentes de quilombo (SILVA, 1999:22). 
Esta hipótese representa um dos mitos fundacionais do agrupamento Kalunga. Outra alternativa possível, obtida através de tradições orais, seria a de que, ao esgotar a atividade mineratória, os bandeirantes voltaram para a região sudeste do país, abandonando seus escravos no sertão goiano. Os negros, então homens livres, embrenharam-se ainda mais nos matagais como forma de defesa contra possíveis ataques de brancos que por ventura resolvessem ir buscá-los. E lá viveram, escondidos por várias décadas, até o surgimento de cidades nas proximidades do território Kalunga ou a incorporação à população local:

$\mathrm{Na}$ realidade, a origem e formação dessa comunidade ainda não está bem esclarecida. Acreditamos, todavia, que os Calunga formaram o quilombo com escravos foragidos do nordeste, especialmente da Bahia, de onde eram trazidos em grandes comboios desde o século XVIII e mesmo no século XVII; do trabalho pesado nas minas de ouro em Goiás, de Mato Grosso e de Minas Gerais; procedendo também das fugas de fazendas goianas e de outros locais do país; havendo ainda a teoria dos que acham que viviam isolados até recentemente e a dos que admitem que conviviam com os índios Avá-canoeiros, com quem se miscigenaram, (SILVA, 1974: 341)

Devido ao grande número de agrupamentos que compõe o território Kạlunga, nas áreas que compreendem as cidades de Monte Alegre de Goiás/GO, Cavalcante/GO e Teresina de Goiás/GO, há a possibilidade de que todas estas hipóteses de mitos fundacionais procedam, considerando que os diversos agrupamentos Kalunga possam ter se formado de maneiras diferenciadas em tempos diferenciados, cabendo à investigação de documentos e tradições orais sobre os quilombos em Goiás as alternativas possíveis de desvendar tal incógnita, não sendo esta a pretensão deste artigo.

\section{As territorialidades kalunga em Goiás.}

A Comunidade Kalunga é um dos tantos grupos de remanescentes de quilombos existentes por todo território Brasileiro. Constituídos por possíveis descendentes de escravos africanos, trabalhadores nas minas de ouro do Estado de Goiás que se refugiaram a mais de 250 anos nos íngremes pouco acessíveis territórios que cercam as trilhas do Rio Paranã.

Atualmente a comunidade é composta por cerca de 3.500 habitantes distribuídos em 204.000 hectares de terra sob cinco núcleos principais: Vão do Moleque, Ribeirão dos Bois, Vão das Almas, Contenda e Kalunga, e por uma centena de pequenas outras localidades que constituem o Sítio Histórico Kalunga. (AGEPEL, 2002).

Devido à dificuldade de acesso, causada pelas longas distâncias e inexistência de estradas apropriadas, e a um senso comum a respeito da inexistência de quilombos após a abolição da escravidão em 1888, estes agrupamentos permaneceram distantes 
do conhecimento comum, com exceção das cidades circunvizinhas, sendo objeto de estudos acadêmicos apenas a partir de Silva (1974) e posteriormente por Baiocchi (1982).

\section{A Economia, Formas de Trabalho e Acesso à Terra}

A principal atividade econômica do grupo é a agricultura familiar rudimentar com fins de subsistência e o plantio de mandioca para a produção de farinha comercializada nas cidades vizinhas.

O cultivo da terra é feito de forma manual e arcaica, baseado no uso de tração animal, pois não há máquinas, não há utilização de irrigação ou qualquer tipo de fertilizante, sendo, pois, estritamente familiar. Há envolvimento da mulher e das crianças no plantio e na colheita.

Na roça era as mulher com os homem trabalhando pra tê o pão de cada dia pra compra o café, o açúcar. E era mulher com homem porque aqui seis tá pensando que é só o homem que trabalha é todo mundo, homem, mulher e filho na roça." (Procópia dos Santos Rosa, 66 Monte Alegre - entrevistada no Vão de Almas dia 15/08/1999)

A falta de modernização na agricultura, aliada à baixa produtividade natural da terra (arenosa e montanhosa), ocasiona uma produção que mal garante a sobrevivência das famílias, exigindo complementação através da compra de produtos na cidade e da criação de gado para obtenção de carne e leite, existindo também criação de aves e suínos, porém em menor escala.

As comunidades Kalunga do entorno de Teresina de Goiás, Cavalcante e Monte Alegre possuem, cada uma, caminhão comunitário doado por programas do governo estadual, que é utilizado como transporte de pessoas e gêneros do meio rural até as cidades.

A prestação de serviços nas grandes fazendas próximas ao território Kalunga e a migração para as cidades vizinhas e grandes centros, como Brasília/DF e Goiânia/ GO, tem se tornado comum nas últimas décadas, fruto da perda de terras tomadas por grileiros e posseiros, fato que causa um crescente processo de empobrecimento dos grupos.

Situação que persiste mesmo diante do fato de "Goiás ter sido o primeiro Estado brasileiro a colocar em prática o dispositivo da Constituição (parágrafo $5^{\circ}$ do artigo 21), que determina o tombamento de sítios detentores de reminiscências históricas dos antigos quilombos. Por meio da lei aprovada em 10 de janeiro de 1991, sancionada pelo então governador do Estado, o território kalunga foi caracterizado como "Patrimônio Cultural e sítio de valor histórico" (AGEPEL, 2002).

Isto ocorre, segundo as tradições orais, porque mesmo sendo o território Kalungá tombado como Patrimônio Cultural e Sítio Histórico, o conflito persiste, devido ao 
fato dos fazendeiros locais, conhecidos popularmente como Paulistas (generalização costumeira feita pelos Kalunga e outros grupos rurais a pessoas invasoras de terras), terem apresentado documentação das terras quilombolas, algumas vendidas pelo próprio Kalunga devido a pressões ou necessidade, e outras conseguidas segundo documentos falsificados, fruto de grilagem, assim como nos mostra o depoimento a seguir:

Os paulistas chegaram em minha terra me dizendo que era pra èu saí, que eles tinha as escrituras. Eu não quis sair. Por vários dias minha casa foi rondada por pistoleros, eles ameaçavam e atiravam pra cima. Um dia quando eu e minha família chegamos da novena que estava acontecendo perto de casa, a casa estava no chão, eles tinham passado o trator em cima dela com tudo dentro, fomo embora de lá com a ropa do corpo. Isso já aconteceu pra mais de 10 anos até hoje ninguém nunca tomo nenhuma providência. Eu meu marido e os menino vivemos ainda hoje de casa em casa, viveno de favor dos outro, (Tereza Pereira Bruno - Diadema dia 25/08/1999).

O processo de legalização das terras é muito lento e burocrático, mantendo o Kalunga, que não tem título de posse da terra, em áreas pouco produtivas, sem investimentos governamentais na agricultura, ainda hoje plantando "à meia" nạs roças de toco cultivadas em terras alheias, ou prestando serviço, temporariamente, em terras dos fazendeiros locais.

A perda de parte do território Kalunga traz uma grande problemática para o grupo. Segundo Moraes (2000), a categoria território representa um espaço social resultado de um processo histórico da relação de um grupo humano com o espaço que o abriga.

Compreendemos assim, que os territórios negros abrangem muito mais que uma simples relação de área de domínio. Para os agrupamentos negros rurais, a terra possui significados divergentes da prática mercantil capitalista, viabilizando a sobrevivência comunitária.

O território, dessa forma, traz, engendrado em si, um repertório de lugares de importância afetiva, simbólica e política, próprios do grupo, que permite a manutenção dos costumes e da cultura que lhes são peculiares.

Desta maneira, a perda de parte do território leva à modificação de antigos costumes referentes à subsistência e à realização das atividades sociais em grupo, como as festas religiosas, cujas partes mais expressivas, segundo as tradições orais, vem se perdendo.

E à inserção de práticas trabalhistas antes não difundidas, como a prestação de serviço em fazendas vizinhas e as formas de trabalho como meeiros e parceiros nas terras ainda não desmatadas, onde os Kalunga agem como mão de obra na frente de expansão. Atenta-se também para a migração de parte considerável da força de trabalho, fruto da expulsão do homem do campo por falta de condições de vida, que se tornam cada vez mais comuns no Sítio Histórico Kalunga. 
Outro fator que contribui sobremaneira para a saída dos Kalunga rumo às cidades é a baixa oferta de escolaridade no campo. Os Kalunga são na maioria analfabetos. Atualmente as crianças têm acesso a escolas fixadas na zona rural. Entretanto, o ensino possui algumas deficiências, pois as escolas são precárias tanto de profissionais (e qualificados!) quanto de material didático. Elas oferecem ensino da $1^{\mathrm{a}}$ à $4^{\mathrm{a}}$ série, onde as crianças estudam todas em uma só sala, e as professoras, que também são Kalunga, possuem normalmente apenas a escolaridade máxima oferecida pela escola local.

\section{Memória dos Grupos Kalunga}

Em relação à bagagem histórica e cultural deste povo, pouco se obtém nas conversações com o grupo. Sempre que o assunto remanescente de quilombo era tocado nas conversas desenvolvidas com o grupo, havia uma certa tensão em se autodenominar enquanto quilombolas, descendente, de negros fugidos, como mostram os trechos das conversas com as Professora Milza Francisca dos Santos, Insulina dos Santos Rosa e Cândida Soares:

(...) sei de descendência com os índios, não com os escravos... Sempre que o pessoal que vem de fora faz reunião, eles fala que somos da descendência com os negros, eu não sei (Milza Francisca dos Santos, 23, Engenho, 22/08/1999.).

(...) eu não entendo sobre esse negócio de Kalunga. Já escutei falar muito, mas não sei. Será que oceis não podia explicar pra gente? (Insulina dos Santos Rosa, 58, Engenho, 22/08/ 1999).

“... só vejo falar que nois é Kalunga, mais não sei porque, não entendo" (Cândida Soares, 56 anos - Diadema, 25/08/2002).

Notamos ainda uma relativa desvinculação com o passado, demonstrando uma espécie de esquecimento intencional de situações tristes ou desagradáveis que revoltam, de um tempo que os envolvidos nas conversas não desejavam recordar (RATTS, 2000).

O mutismo em torno de assuntos de difícil rememoração como a discriminação e o tempo da escravidão, vividos pelos pais e avós, oscila entre o silêncio e o esquecimento. Corrobora com essa afirmação a entrevista a seguir:

... Não posso falar de coisas que acontecem antes de eu nascer, coisas que não vivi, porque assim estaria mentindo, só falo das coisas que eu me lembro, (Simão Pereira Dias dos Santos, 62 - Vão de Almas).

Ao encarar a categoria escravo enquanto sinônimo de negro, toda carga histórica obtida junto ao sistema escravista revive na memória, principalmente dos mais velhos. Tudo oscilando entre um misto de silêncio e esquecimento do passado, o que resulta em uma aversão à condição de negro no presente. Torna-se, assim, possível 
identificar uma perda parcial da identidade étnica deste povo ${ }^{1}$.

A política do dominador, segundo suas escalas de valores sociais, extremamente racistas, conduz o negro Kalunga a criar uma realidade simbólica e alienadora, fugindo de sua própria realidade de descendente de negros cativos marginalizados por uma sociedade branca à procura de uma identidade étnica simbólica, normalmente "superior" à sua, capaz de o posicionar de forma aceitável no meio social.

Porém, o que se nota é uma recente necessidade de se reconhecer quilombola por parte dos Kalunga, devido aos direitos legais sobre as terras já demarcadas enquanto Sítio Histórico, ação esta que se concretizou devido ao Artigo 68 do Ato das Disposições Constitucionais Transitórias da Constituição Federal.

Assim, em 05 de outubro de 1988, o quilombo é reintroduzido dentro das disposições transitórias legais, na Constituição da República Federativa do Brasil, através da promulgação do já citado Artigo 68 que versa o seguinte:

"Aos remanescentes das comunidades de quilombos que estejam ocupando suas terras é reconhecida à propriedade definitiva, devendo o Estado emitir-lhes os títulos respectivos".

Preceito que Almeida assim interpreta:

Uma leitura possivel é que os legisladores tenham partido do passado para chegar à idéia de quilombo e o trataram como mera "sobrevivência", reeditando elementos da definição jurídica do período colonial. Mantendo-se tal definição o estado de "escravo fugido" e longe dos domínios das "fazendas" persistiria de certo modo, como identificação lega,l (ALMEIDA, 1996:16).

O fator isolamento, bem como a noção de fuga, entre outros aspectos, mantiveram-se enquanto forma de constituição do quilombo, onde os negros descendentes foram legalmente denominados como "remanescentes de quilombo".

Vê-se que , mesmo nos dias atuais, a realidade dos quilombos é encarada como um fenômeno do passado, devido ao conteúdo literário ainda colonial preservado no Art. 68, promulgado em 05 de outubro de 1988 na Constituição da República Federativa do Brasil.

Neste aspecto, o isolamento passa a constituir um ponto de relevância nos textos acadêmicos e jornalísticos a respeito dos quilombolas, entoando um ar exótico e misterioso sobre os grupos desta natureza.

Ao questionar o Kalunga Domingos dos Santos Rosa no que se refere à questão do isolamento, tanto em sua concepção quanto na concepção que ele imagina que as pessoas de fora do grupo tenham a respeito do Kalunga enquanto grupo isolado. diz ele:

\footnotetext{
'Identidade étnica é o nivel de consciência individual ou grupal das origens ancestrais capaz de determinar a aceitaşão, reconhecimento e sua auto-afirmaşão social e cultural a partir desse nível de consciência alcançada, MOURA (1994: 156).
} 
É porque nois é dessa região aqui, nunca teve assim um conforto aqui pra nois, e o pessoal da cidade fala que nois mora aqui no mato, agora nois não mora no mato não, nois mora é em casa, ninguém mora no mato, quem mora no mato é bicho (Domingos dos Santos Rosa, 52,

Vão de Almas, 15/08/1999).

Assim, percebe-se que a idéia de isolamento, com todos os seus significados, intensifica o racismo e o preconceito em relação aos habitantes de agrupamentos negros rurais, reproduzindo e reforçando a idéia de atraso e inferioridade do sertão em relação à metrópole.

Outro ponto de reflexão levantado por Almeida (1996) é que se no passado a formação de quilombos representava uma ação criminosa, repreendida por lei, atualmente passa a ser considerada uma categoria de autodefinição, utilizada para reparar um dano. Isso resulta em um problema junto aos camponeses de ascendência escrava, seja africana ou indígena, que têm dificuldade de se autodenominarem quilombolas devido ao passado marginal desta instituição.

\section{Religião}

Os grupos Kalunga apresentam, em sua maioria, uma espécie de catolicismo popular, exercido nas novenas e missas que assistem nas festas anuais.

São devotos de Nossa Senhora da Abadia, da Santa Trindade, de São Sebastião e outros santos cultuados no local, como a Nossa Senhora das Neves que deu origem a uma festa em sua homenagem no agrupamento Vão de Almas, uma das tantas e animadas festas, regadas a bebidas, danças, rituais típicos e muito forró. Os festejos ocorrem no período de maio a outubro, quando então os agrupamentos se reúnem em homenagem aos diversos santos padroeiros:

Aqui somos tudo católicos, devotos da Nossa Senhora da Abadia que é a dona dessas terras aqui, (Justino dos Santos Rosa - Vão de Almas, 15/08/1999).

Há realização de missas anuais nos agrupamentos, normalmente durante as festas, onde o padre realiza casamentos, batizados e recebe confissões. Tais eventos são considerados importantíssimos para os Kalunga, que fazem questão de batizar seus filhos e se casar sob as benções do padre.

De acordo com MARTINS (1993), o batismo aparece para pessoas de grupos étnicos não brancos como o sinal que dava o reconhecimento de cristão, ou seja, de humano, pois a sociedade declara facilmente a animalidade de grupos, porque falam outra língua, possuem outra cor ou costumes e crenças diferentes.

É importante ressaltar, entretanto, que os Agrupamentos Kalunga, abrangidos na pesquisa, apresentam variações consideráveis, e que a generalização destas características ofende às especificidades encontradas. Desta forma, torna-se necessário que 
façamos reflexões direcionadas a cada uma delas afim de se entender não a parte, mas o todo, o geral.

\section{Áreas da pesquisa}

\section{Vão de Almas}

O Vão de Almas é um dos cinco principais núcleos que compõem o Sítio Histórico Kalunga. Situado a aproximadamente $15 \mathrm{Km}$ da cidade de Teresina de Goiás/GO, é palco de uma das mais importantes festas religiosas do grupo, que acontece todos os anos, nos dias 13,14 e 15 de agosto, onde os Kalunga fazem louvor à Nossa Senhora da Abadia, padroeira da região.

A situação sócio-econômica dos moradores locais não diverge das descrições apresentadas anteriormente.

O local da festa não possui estrada de acesso, água encanada, esgoto e nem energia elétrica. Só pode ser alcançada via canoa ou pelas trilhas de uma serra denominada localmente de pula-pula, num árduo percurso que a pé dura até seis horas de viagem. No entanto, essas dificuldades não impedem que grupos Kalunga das várias localidades que compõem o Sítio Histórico participem ativamente dessa festa, visto que são identificadas, a cada ano, aproximadamente 2000 pessoas prestigiando o evento.

O local possui uma interessante organização espacial. Há uma grande quantidade de ranchos feitos de madeira, barro e teto de folhas de coqueiro, utilizados pelas famílias Kalunga somente no período da festa, pois no local desta não existem moradores fixos. Existe também um grande rancho destinado à dança de forró, com venda de ingressos.

As casas de uso temporário na festa assemelham-se às moradias fixas, visitadas pelo grupo ao longo da viagem, mas não são suficientes para todos, por isso algumas famílias dormem em redes no meio do mato durante o período de duração da festa.

A festa é caracterizada principalmente pela religiosidade e realização de rituais característicos da cultura Kalunga, mas também tem como traço marcante o comércio de bebidas e alimentos, contando com comerciantes Kalunga e com terceiros.

Tal fato representa mais um item desmistificador da idéia de isolamento total imposta ao grupo, pois o que se nota é uma integração bem fundamentada do Kalunga com alguns costumes urbanos, tendo como exemplo a prática comercial pautada na moeda, como nos mostra trecho da entrevista:

Tenho comércio na roça também, eu vou na rua trago as coisas e vou vendendo pro pessoal. Na hora que acaba eu vou busca mais, (Simão Pereira Dias dos Santo, Vão de Alma, 14/08/ 1999). 
Os Kalunga não apresentam qualquer característica marcante que os remeta ao isolamento total, tanto na fala quanto no vestuário, mostrando ainda grande eloqueência e oportunismo para realizar reivindicações nas tradições orais oferecidas em campo, como mostra a entrevista a seguir:

Os políticos de Monte Alegre não vale nada, na época de eleição eles vai lá e promete, mas nunca vi resultado dos prefeito. Todo mundo vota, inclusive eles estão tirando título aqui na festa, (Procópia dos Santos Rosa, 66 - Monte Alegre - entrevistada no Vão de Almas dia 15/ 08/1999).

A parte cultural mais expressiva da festa ocorre no dia 15 de agosto com a coroação da rainha e do imperador. Eles saem em cortejo em volta da capela, seguidos pela população. Depois, recepcionam a todos, servindo bebidas, biscoitos e bolos. A expectativa é para saber quem será o responsável pela festa do próximo ano.

Neste clima da festa os Kalunga realizam danças e rituais, que se assemelham às congadas realizadas por grupos negros em cidades interioranas de Goiás e outros estados.

As procissões são iluminadas à luz de vela de cera de abelha e demonstram uma dança chamada sussa, onde as mulheres dançam equilibrando uma garrafa na cabeça durante a performance, sendo estas apresentações um dos principaị pontos de atração da festa.

As pesquisas não sabem dizer com exatidão a origem dessas comemorações. Acredita-se que poderiam ser uma recriação de um ritual religioso branco, incorporado pelos negros já aqui no Brasil; ou poderiam ter sido trazidas da África, numa representação das festas de coroação dos reis do Congo, por exemplo.

Existe a celebração de uma missa anual onde são feitos casamentos, batizados e confissões. A cobrança de dízimo é tradicional, apesar da pobreza das pessoas do local. Sermões severos e hinos proferidos em culta linguagem são repetidos com dificuldade pelas poucas pessoas normalmente presentes na celebração.

\section{Vão do Moleque}

O Vão do Moleque é outro dos cinco principais núcleos que compõe o Sítio Histórico Kalunga. Situado a aproximadamente $13 \mathrm{Km}$ da cidade de Cavalcante/ GO, é palco de outra importante festa religiosa do grupo, que acontece todos os anos, na primeira metade do mês de setembro.

A ampla praça ao redor da pequena igreja transforma-se em colônia de barracas de paus e folhas de coqueiro. De uma só vez, a comunidade venera vários santos, entre os quais se destaca São Gonçalo, representado com violão nas mãos. É considerado um santo "farrista". Segundo a tradição, o santo promovia bailes noturnos numa região ameaçada pela onda de prostituição. Cansadas de dançar, as pessoas 
caíam no sono, sendo, assim, preservadas, pelo santo, das práticas imorais.

Todas as noites, a comunidade se reúne para as rezas e devoções. As pessoas cantam música de louvor e ladainhas em latim. Na noite que dá início aos festejos, após as rezas no interior da capela, saem em procissão, dando três voltas ao redor da capela e dançando a tradicional dança, a sussa, em volta do mastro.

Durante os dias da festa ocorrem as missas com Batismos, Crismas, Primeira Comunhão e Matrimônios.

Em relação à condição sócio-econômica, o núcleo não difere expressivamente das demais áreas, tendo exceção a questão que envolve o processo migratório, fruto das perdas expressivas de território e precariedade nas condições de vida, fator este que se faz bastante expressivo dentro do Sítio Histórico.

Um fator marcante nas conversas com o grupo é a ansiedade que este apresenta com a modernização das técnicas agrícolas, a fim de aumentar a produtividade visando à comercialização de alimentos. Anseiam pela construção de uma estrada ligando o Vão do Moleque a Cavalcante, bem como a construção de escolas que possuam ensino superior à $4^{\circ}$ série e benfeitorias locais.

Tais fatores puderam ser identificados em conversas que tivemos com o Senhor Pedro Manoel dos Santos, que defendeu veementemente a construção da estrada alegando que a comunidade tem sofrido duras penas pela dificuldade de locomoção do meio rural até as cidades, quando necessita fazer compras, comẹrcializar algum produto excedente ou quando acometido por doenças.

Relatou-nos, também, que a falta de beneficiamento na terra diminui a produção, causando fome e expulsando parte da população para as cidades. Isso, aliado à falta de instrução no campo, tem agravado o êxodo principalmente das populações jovens do lugar.

\section{Engenho II}

O grupo Engenho está situado há aproximadamente $15 \mathrm{Km}$ da cidade de Cavalcante/GO, cuja única via de acesso é uma estrada de terra, trafegada por veículos apropriados para trilhas, ou por animais, devido às constituições geográficas do território, formadas por serras íngremes e pedregosas.

Este agrupamento apresenta a condição de remanescente de quilombo no modo da manutenção de certas tradições locais, como a forma de construção das casas, os códigos éticos de convívio social, a afetividade e as práticas de lazer, bem como uma série de benfeitorias recebidas com a implementação do Patrimônio Cultural e Sítio Histórico.

Várias foram as modificações introduzidas na qualidade de vida local após a aquisição de uma camionete, que faz o percurso agrupamento Engenho e cidade de Cavalcante de uma a duas vezes por semana: a melhoria da infra-estrutura da escola estadual do agrupamento com a vinda de televisão, vídeo e antena parabólica, ener- 
gia solar, a visita freqüente de agentes de saúde, a aposentadoria dos idosos, a distribuição mensal de cestas de alimentos, e a tentativa de troca gradativa do material de construção das casas antes feitas por tijolos de adobes e telhados de palhas trançadas, altamente propensas a incêndios, por telhas e tijolos de barro vindos da cidade.

As melhorias foram significativas, porém não atenderam ainda completamente às necessidades e às reivindicações dos moradores que sempre comentam a necessidade de uma estrada asfaltada, que facilite o acesso à cidade, a fim de evitar situações de risco como morte ou acometimento de doenças graves não atendidas pelo sistema de saúde atual, investimento na agricultura, no turismo e principalmente a falta de terras para plantio, atividade principal do grupo.

$\mathrm{O}$ que caracteriza a principal peculiaridade deste grupo são as formas de uso e posse da terra, que vêm se modificando drasticamente no decorrer da história da existência e constituição do território, devido à perda de grande parte do mesmo. Isso fez com que este agrupamento esteja hoje em uma porção de terra que se restringe ao espaço residencial, dando ao mesmo a característica de uma pequena vila rural.

A perda de parte do território força a modificação de antigos costumes referentes à agricultura e à realização das festas religiosas, inserindo formas de trabalho entre os Kalunga e também junto aos grandes fazendeiros antes não tanto difundidas, intensificando a exploração do camponês expropriado pelo latifúndio.

Vários foram os depoimentos a respeito da violência na perda de parte deste território e das conseqüências destas mudanças, como nos mostra a entrevista gravada a seguir:

- Ouvimos dizer, que o Senhor passou por alguns problemas com posseiros, que lhe tomaram a terra. O Senhor poderia nos relatar como isso aconteceu?

- Sr José: Eles correram comigo desse lugar onde meu pai morava antigamente.

- Eles quem?

- Sr José: É... o pessoal que comprou aí, os paulista

- E o que aconteceu neste lugar?

- Sr José: Tem o Abel, que é um parente meu, ele mora lá em Cavalcante, nos era uma família, ai o Abel foi e vendeu para eles foi e me arrancou de lá.

- O Abel vendeu um pedaço, e a terra do Senhor era a do lado?

- Sr José: Era a do lado. Naquele tempo a cerca que nois cercava era de pau, não tinha essa de arame que hoje tem, por isso o Abel vendeu a dele e a minha foi também. O Abel era meu primo, é tudo de uma familia só, tudo dos Maia.

- Como os paulistas fizeram para tirar o senhor da sua terra?

- Sr José: Eles mando eu sai desse lugar aí. Lá só de abacate eu tinha 18 pé, mais 70 tocera de banana mais de 100 tocera de cana, a roça tava formadinha, tinha café, tudo eu tinha.

- Aí o senhor saiu da terra porque eles mandaram?

- Sr José: Saí. Ainda tem as frutera até hoje lá. Tem mangueira, dois pé dé abacate. No resto eles meteram o trator e ranco tudo. 


\section{- E o que eles plantam hoje lá?}

Sr José: Não estão plantando nada. Eles arô lá, o Sr. Paulim eles plantava arroz, plantava milho, aí ele faltou, agora tá parado lá, tá tudo capoerão

- O senhor ainda trabalha na roça?

- Sr José: Eu vou. Planto numas terras perto da Fazenda Paciência, fica a uma légua daqui. Eu sou roxo pela roça... Sou roxo pela roça. (José Francisco Maia, 62, Engenho, dia 22/08/1999).

As terras cedidas aos Kalunga para plantio em grandes fazendas, como a Paciência, citada pelo Sr. José Francisco Maia, normalmente são terras que contém ainda mata nativa, e os Kalunga são usados para realizar o desmatamento e fazer o beneficiamento primário através das plantações em roças de toco, num período curto de dois a três anos. Depois disso, o fazendeiro utiliza os locais para plantar pasto ou produtos para o mercado.

Assim, acreditamos que a perda de expressiva parte do território Kalunga no Engenho, além de impor práticas diferenciadas de trabalho, tem ainda jogado os Kalunga em circunstância de população na frente de expansão, sujeitos a todas as adversidades que esta situação de risco oferece.

\section{Diadema}

Diadema está situada a aproximadamente $10 \mathrm{Km}$ da cidade de Teresina de Goiás/ GO. As famílias estão espalhadas em pequenas propriedades por vasto local. Esta área também foi beneficiada com a demarcação de terras do Sítio Histórico Kalunga, tendo algumas propriedades já legalizadas. Há no local uma escola feita de alvenaria e uma fábrica comunitária de farinha, recentemente acabada. As más condições de vida e o índice de analfabetismo são semelhantes aos demais grupos visitados.

Em relação às demais comunidades visitadas esta é a que se encontra mais próxima da cidade. Daí pode-se observar, também, como no Engenho há grande ocorrência de invasões nas terras.

Ouvimos vários depoimentos de moradores a esse respeito, como o do Sr. Romão Magno dos Santo, 78 anos, morador do local. Ele nos relatou, em entrevista gravada, sua história nas terras de Diadema, a luta pela posse da terra, as tentativas de desapropriação dos Paulistas e as emboscadas sofridas por jagunços contratados para assassinar:

...Eles falaram que era pra eu sair de qualquer jeito porque tinham comprado e pagado a terra, eles não iam aceitar ninguém aqui. Eles tiro uma picada aí, no fundo ainda tem a marca aí. E disseram: de hoje em diante na hora que cercar aqui nois não vai deixar couchete nenhum para vocês sair, o direito de vocês andar aqui e só daqui para trás, tora arame oceis 
não tora, e para não ser assim vocês tem que sair, eu não quis sair e consegui a posse de parte da terra, (Romão Magno dos Santo, 78, Diadema, dia 24/08/1999).

A ação do estranho, no caso os invasores das terras do Sr. Romão, conforme MARTINS (1993), não vem introduzir nada na vida das populações. Vem sim lhes arrancar o que possuem de vital para sua sobrevivência, tanto no aspecto econômico quanto cultural e político. Para esse fim, utilizam intimidações que vão da simples hostilidade e imposição de limites territoriais, até o uso de violência e morte, através da ação de pistoleiros, como nos relata ainda o Sr. Romão:

Teve um homem que pois até pistolêro aqui numa casa ali na frete que eu acho que ele levanto até de noite porque eu não escutei nem rebater prego ai e pois lá um pistoleiro. O pistolêro era cachacêro nê! E foi lá pro Geraldo e tava contando prosa pro Geraldo, que ele tava aí era a fim de me mata. Na mesma hora eu cheguei e ele tava comigo é Sr. Romão daqui Sr. Romão de lá, e o Geraldo falo: Mas Aurélio, ocê tem cara de conversar assim mais Romão, olha Romão ele tá ai com essa bondade com você mais ele veio aqui foi pra te matar, falou tudo pra nois agora a pouco, ele tá aqui e pra matar você, se segura, anda armado. Eu falei então é assim? Ele disse: não, não é nada. Então ele fugiu, largô a mulher e foi se embora. Ele queria me matar por causa da terra, (Romão Magno dos Santo, 78, Diadema, dia 24/08/1999).

O senhor Romão teve as terras legalizadas pelo IDAGO no período do tombamento do Sítio Histórico, porém adquiriu somente dez alqueires e não cinqüenta como possuía anteriormente.

Atualmente, ele e sua esposa vivem da aposentadoria que recebem do Governo. Não plantam mais, devido à pouca extensão de terra e à falta de beneficiamento na mesma, que impossibilita o cultivo no local. Fato tal que ilustra a situação de grande parte dos moradores do lugar, tanto em relação ao processo de legalização das terras quanto em relação às formas de vida adotadas após a perda de partes de seu antigo território.

Desta maneira, observamos que apesar da realização das políticas públicas em benefício aos remanescentes de quilombo, ainda resta muito a ser feito, tanto em relação ao aprimoramento da lei, que se mostrn reducionista, quanto ao tempo que tenta tornar genéricas as formas de uso e posse da terra, sendo extremamente variadas, bem como oferecer, além da terra, condições para que as pessoas permaneçam no campo, ao invés de serem expulsas pelas péssimas condições de vida que enfrentam.

\section{Considerações finais}

Do exposto, emergem questões importantes a serem refletidas em relação à comunidade Kalunga, nos aspectos referentes à cultura, trabalho e relação com a terra, visto que tais elementos caminham emparelhados, dando forma e sentido às relações que dentre outros fatores, compõem a sua realidade. 
No que diz respeito à cultura, vimos um horizonte vastíssimo, pois apesar da comunidade apresentar uma realidade simbólica e alienadora, criada como fuga de sua própria realidade de descendente de negros cativos marginalizados, fruto de uma política racista do dominador, o negro Kalunga se expressa ricamente e mantém vivos costumes no trabalho, danças, rezas e manifestações religiosas próprias.

Os Kalunga, como qualquer grupo camponês, mantém suas raízes fixadas na terra que lhes pertence, numa relação sentimental e carregada de significados, ligados à sobrevivência material e cultural. No entanto, estas raízes vềm sendo arrancadas, ao longo do tempo, pela ação de grileiros e posseiros que lhes roubam a terra e os expulsam do local de origem, tirando-lhes não somente a fonte de sobrevivência material, mas a própria identidade.

Assim, acreditamos que a comunidade Kalunga necessita de um apoio governamental mais expressivo, que lhe ofereça segurança em relação à posse e manutenção da terra; melhores condições de vida com implementações no campo da saúde e educação dignas a fim de amenizar o crescente processo de migração para as cidades. Necessitam, ainda, de construção de estradas, dentre outros elementos, que garantam seus direitos de cidadãos, a fim de que este grupo étnico possa conquistar o respeito que os liberte dos estigmas e exotismos que os enquadram como bárbaros habitantes do outro lado da fronteira, sendo reconhecidos sim, como pessoas, seres humanos dotados de direitos de participação social.

Resumo: A comunidade Kalunga é um dos tantos remanescentes de quilombos existentes por todo território brasileiro. Compõe-se por famílias de prováveis descendentes de escravos africanos, trabalhadores nas minas de ouro do Estado de Goiás que se refugiaram a mais de 250 anos nos íngremes e pouco acessíveis territórios que cercam as trilhas do Rio Paranã.

Palavras Chaves: Kalunga, quilombo, terra, território, trabalho.

Abstract: The Community Kalunga, is a of the many of Quilombos be alive for all Brazilian territory. Constituted for family's of descendants os africans enslave, workers in the gold of the Goiás state, that take refuge the more of two hundred and fiffy years in the hard and little territory access that fence in the tracks of the Parana river.

Key Works: Kalunga, quilombo, land, territory, work

\section{BIBLIOGRAFIA}

AGEPEL. Disponível em: http://www.agepel.goias.gov.br/municipios goianos/ historiadegoias.htm

ALMEIDA, A. W. B. de. 1996. Semantologia face a novas identidades. In: Projeto Vida de Negro. Frechal, terra de preto, quilombo reconhecido como reserva extrativista. São Luiz: SMDDH/CCN-MA.

ALMEIDA, Maria Geralda de 1996. Em Busca do Poético do Sertão. Espaço e Cultura. UERJ, NEPEC, Rio de Janeiro, n. 6, p. 37-48.

CAROS AMIGOS. 1998. São Paulo: Casa Amarela. Mensal. Quilombos: Nossa Terra tem mais Donos - Terra de Preto. 
KARASCH, Mary. 1996. Os quilombos do ouro na capitania de Goiás. In: REIS, J. J.; GOMES, F. dos S. Liberdade por um fio - história dos quilombos no Brasil. São Paulo: Companhia das letras. Pp. 240-263.

LUNA, Luiz. 1976. O Negro na Luta contra a Escravidão. $2^{\mathrm{a}}$ ed. Rio de Janeiro: Cátedra.

Quilombos no Nordeste e no Brasil Central.

MOURA Clovis. 1994. Dialética Radical no Brasil Negro. São Paulo: Anita.

MORAES, A. C. R. I2000. Introdução In: MORAES, A. C. R. Bases da formação territorial do Brasil: o território colonial brasileiro no "longo" século XVI. São Paulo: Hucitec pp. 15-27.

MARTINS. José de Souza. 1993. A Chegada do Estranho. São Paulo: Hucitec.

MARTINS. José de Souza. 1997. Fronteira. A Degradação do Outro nos Confins do Humano. Co-edição do Programa de Pós-graduação. Departamento de Sociologia da Faculdade de Filosofia, Letras e Ciências Humanas da USP. São Paulo: Hucitec.

MATTOSO, Kátia M. de Queiroz. 1982. Ser Escravo no Brasil. São Paulo: Ed. Brasiliense. $3^{\circ}$ ed.

PALACIN, Luiz. 1972. Goiás 1722 - 1822: estrutura e conjuntura numa capitania de minas. Goiânia: Oriente.

RATTS, Alecsandro J. P. 2000. O mundo é grande e a nação tambẹm: identidade e mobilidade em territórios negros. 2000. 184 f. Tese (Doutorado em Antropologia Social) - Faculdade de Filosofia, Letras e Ciências Humanas, Universidade de São Paulo, São Paulo.

SILVA, Ana Van Meegen. 1999. Identidade Étnica de uma comunidade remanescente de quilombos. $102 \mathrm{f}$. Monografia de conclusão de Curso. Universiteit em Amsterdã-Holanda, 1999. Disponível em: A.v.Meegen@ubvu.vu.nl< A.v.Meegen@ubvu.vu.nl> 